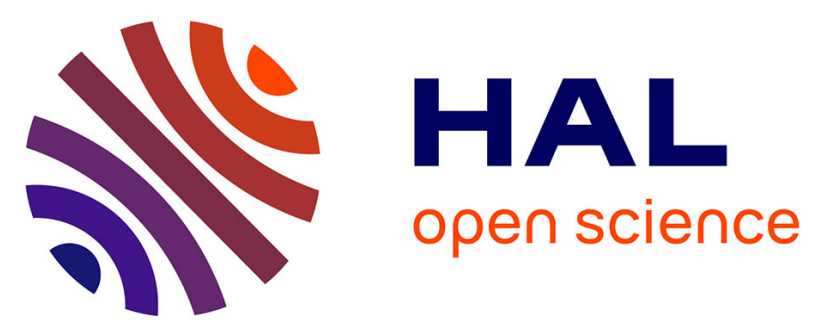

\title{
Systematic investigation of the annealing temperature and composition effects on the dielectric properties of solgel BaxSr1-xTiO3 thin films
}

Delphin Levasseur, Heba Badr El Din Badr El-Din El-Shaarawi, Sébastien Pacchini, Anthony Rousseau, Sandrine Payan, Guillaume Guegan, Mario Maglione

\section{To cite this version:}

Delphin Levasseur, Heba Badr El Din Badr El-Din El-Shaarawi, Sébastien Pacchini, Anthony Rousseau, Sandrine Payan, et al.. Systematic investigation of the annealing temperature and composition effects on the dielectric properties of solgel BaxSr1-xTiO3 thin films. Journal of the European Ceramic Society, 2013, 33 (1), pp.139-146. 10.1016/j.jeurceramsoc.2012.07.041 . hal-00797624

\section{HAL Id: hal-00797624 \\ https://hal.science/hal-00797624}

Submitted on 6 Mar 2013

HAL is a multi-disciplinary open access archive for the deposit and dissemination of scientific research documents, whether they are published or not. The documents may come from teaching and research institutions in France or abroad, or from public or private research centers.
L'archive ouverte pluridisciplinaire HAL, est destinée au dépôt et à la diffusion de documents scientifiques de niveau recherche, publiés ou non, émanant des établissements d'enseignement et de recherche français ou étrangers, des laboratoires publics ou privés. 


\title{
Systematic investigation of the annealing temperature and composition effects on the dielectric properties of solgel $\mathrm{Ba}_{x} \mathrm{Sr}_{1-\mathrm{x}} \mathrm{TiO}_{3}$ thin films
}

\author{
Authors names and affiliations : \\ *D.Levasseur ${ }^{1,2}$ (corresponding author) : levasseur.d@icmcb-bordeaux.cnrs.fr \\ H.B. El-Shaarawi ${ }^{3}$ : heba_elshaarawy@yahoo.com \\ S. Pacchini ${ }^{3}$ : spacchini@ntu.edu.sg \\ A. Rousseau ${ }^{1}$ :rousseau@icmcb-bordeaux.cnrs.fr \\ S. Payan ${ }^{1}$ : payan@icmcb-bordeaux.cnrs.fr \\ G. Guegan ${ }^{2}$ : guillaume.guegan@st.com \\ M. Maglione': maglione@icmcb-bordeaux.cnrs.fr \\ ${ }^{1}$ CNRS, Université de Bordeaux, ICMCB, UPR9048, F-33608 Pessac, France \\ ${ }^{2}$ ST Microelectronics, 16 Rue Pierre et Marie Curie, 37100 Tours, France \\ ${ }^{3}$ LAAS-CNRS, Université de Toulouse ; UPS, INSA, INP, ISAE ; LAAS ; Toulouse, France \\ * Corresponding author details : \\ Delphin Levasseur \\ ICMCB - CNRS, UPR9048, 87, Avenue du Docteur Schweitzer \\ 33608 PESSAC cedex (France) \\ Tel : $0033(0) 540006256$ \\ Fax : $0033(0) 540002761$ \\ Mail :levasseur.d@icmcb-bordeaux.cnrs.fr
}

\begin{abstract}
In this work, $\mathrm{Ba}_{\mathrm{x}} \mathrm{Sr}_{1-\mathrm{x}} \mathrm{TiO}_{3}$ solgel thin films ( $\mathrm{x}=0.7,0.5$ and 0.3 ) deposited on $\mathrm{Pt} / \mathrm{Si}$ substrate and post-annealed at different temperatures have been investigated. A systematic study of the structure, microstructure and of the dielectric properties have been achieved for each composition. To our knowledge, for the first time, a systematic effect of post-deposition annealing temperature and composition is reported. For each $\mathrm{Ba} / \mathrm{Sr}$ ratio, higher annealing temperature leads to crystallinity improvement and to grain growth. A shift of the ferroelectric to paraelectric transition toward the bulk Curie temperature with the increase of the annealing temperature is shown. These results are correlated with the increase of the permittivity, tunability and dielectric losses measured on MIM capacitors at low frequency. Moreover, the high frequency results, between $800 \mathrm{MHz}$ and $30 \mathrm{GHz}$, are in very good agreement with low frequency measurements, and show a huge tunability up to $80 \%$ under $600 \mathrm{kV} / \mathrm{cm}$.
\end{abstract}

\section{Keywords}

Films, Grain size, Dielectric Properties, BaTiO3 and titanates, Capacitors 


\section{1- Introduction}

Over the past few years, ferroelectric thin films have been widely considered for tunable microwave devices. A good lead free candidate is $\mathrm{Ba}_{\mathrm{x}} \mathrm{Sr}_{1-\mathrm{x}} \mathrm{TiO}_{3}$ (BST), showing a high permittivity, a good tunability, and low dielectric losses. It is well known that downsizing ceramic to thin film, these dielectric properties are affected.

BST thin films can be prepared by several techniques such as MOCVD, RF-magnetron sputtering, pulsed laser ablation and sol-gel processes [1-4]. Among these techniques, sol-gel deposition is of a great industrial interest, using simple equipment and fast process. In addition, it offers some advantages, such as good film homogeneity and stoichiometry and large area deposition.

The main goal for applications is to understand and control the effect of the composition and of process parameters on the properties. Many studies have been carried out concerning the $\mathrm{Ba} / \mathrm{Sr}$ ratio effect, on the optical properties [5-8], on nanomechanical characteristics [9], on the electrical properties [10-11] or dielectric properties at low frequencies [12] and microwave frequencies [13-15]. The most influential process parameter common in many synthesis or deposition techniques is the temperature [16-18]. Wu et al explored the effect of the annealing temperature for various compositions [19] on the dielectric properties but only at low frequency.

In this paper, a study of the structure, microstructure and of the dielectric properties at low and high frequencies of BST sol-gel thin films deposited by spin coating is presented, in which the effects of post-deposition annealing temperature and composition are investigated. To our knowledge, for the first time, a systematic behavior in terms of grain sizes, ferroelectric to paraelectric transitions and dielectric properties of three different $\mathrm{Ba}_{\mathrm{x}} \mathrm{Sr}_{1-\mathrm{x}} \mathrm{TiO}_{3}$ film compositions is reported, with $\mathrm{x}=0.7$ (BST70), $\mathrm{x}=0.5$ (BST50) and $\mathrm{x}=0.3$ (BST 30). Radio Frequency measurements are also presented: a very high tunability at $10 \mathrm{GHz}$ is reported.

\section{2- Experimental procedure}

The $\mathrm{Ba}_{\mathrm{x}} \mathrm{Sr}_{1-\mathrm{x}} \mathrm{TiO}_{3}$ precursor sols used in this study were purchased from Mitsubishi Material Corporation, Japan. Thin films of approximately the same thickness were prepared by spin coating using three different compositions with $\mathrm{x}$ equal to $0.7 / 0.5 / 0.3$. The films were deposited on $\mathrm{Pt} / \mathrm{Si}$ 
substrate. Each coated layer was pyrolyzed, and the process was repeated in order to obtain the desired thickness. Finally the whole films were post-annealed under oxygen at various temperatures from 600 to $800^{\circ} \mathrm{C}$. The phase formation and the film crystallinity were analyzed using a Panalytical X'pert MDP X-ray diffractometer in Bragg-Brentano geometry, with a 40kV working voltage. The grain size and morphology were investigated by scanning electron microscopy (SEM) using a Nova NanoLab 600 microscope at $15 \mathrm{kV}$ for the top view images, and a JEOL 6700 at $5 \mathrm{kV}$ for the cross section image.

So as to study the dielectric properties at low frequencies of our films, Metal-Insulator-Metal (MIM) structures were formed by depositing top electrodes by RF-magnetron sputtering at room temperature through a shadow mask. These $100 \mathrm{~nm}$ thick top electrodes were circular with a diameter of $600 \mu \mathrm{m}$. The capacitance-voltage $(\mathrm{C}-\mathrm{V})$ characteristic of MIM capacitors were investigated at room temperature using a Süss Microtec PM5 probe system and a Hewlett Packard 4194A Impedance/Gain Phase Analyzer. The C-V curves were measured at $100 \mathrm{kHz}$ and $0.1 \mathrm{~V} \mathrm{AC}$ signal, and the dielectric permittivity was then calculated using capacitance, and the dimensional parameters: the thickness $d$ obtained from cross section SEM images, and top electrode areas $A$ measured with an optical microscope. The capacitance-temperature (C-T) characteristics were carried out in a home built measurement cell. The samples were mounted inside a furnace, in a vacuum chamber equipped with a cryogenic cooler. The furnace temperature was regulated with a Eurotherm device and a platinum resistance temperature sensor fixed on the furnace. A second Pt sensor was fixed in the substrate holder to give the sample temperature. The measurements were performed under helium atmosphere providing a good thermal contact. This system can afford a large temperature control range from $200^{\circ} \mathrm{C}$ to $150^{\circ} \mathrm{C}$. Capacitance-Frequency (C-F) characteristics were measured with a Wayne Kerr 6500B Impedance Analyzer each 15 seconds during the sample temperature ramp up rate $(0.5 \mathrm{~K} / \mathrm{min})$ thereby giving C-T curves at many frequencies.

The RF properties were investigated on Parallel Plate Capacitors (PPC) shown in Fig. 1. A design consisting of two imbricate gold circle patches as signal and ground electrodes is patterned over BST layer. Two PPCs have been fabricated of dimensions given by:

Capacitor 1 (Denoted by $\mathrm{C}_{\mathrm{a}}$ ): $\mathrm{a}_{\mathrm{a}}=20 \mu \mathrm{m}, \mathrm{b}_{\mathrm{a}}=60 \mu \mathrm{m}, \mathrm{c}_{\mathrm{a}}=280 \mu \mathrm{m}$.

Capacitor 2 (Denoted by $\mathrm{C}_{\mathrm{b}}$ ): $\mathrm{a}_{\mathrm{a}}=30 \mu \mathrm{m}, \mathrm{b}_{\mathrm{a}}=60 \mu \mathrm{m}, \mathrm{c}_{\mathrm{a}}=280 \mu \mathrm{m}$. 
These dimensions take into account the RF probes pitch $(150 \mu \mathrm{m})$ needed to be satisfied for the measurement process (Fig. 1 (b)). One port reflection measurements of the parallel plate varactors at frequency ranges from $800 \mathrm{MHz}$ to $30 \mathrm{GHz}$ are carried out by using the Anritsu 37397C vector network analyzer (VNA) and Picoprobes with $150 \mu \mathrm{m}$ GSG coplanar pitch. The bias voltage is supplied via the internal bias tee of the VNA that allows biasing up to $40 \mathrm{~V}$, while SOLT calibration is used. This method was first proposed by Ma et al. in [20]. One of the advantages of this test structure is its minimized parasitic $\mathrm{R}$ and $\mathrm{L}$, in addition to its easy fabrication.

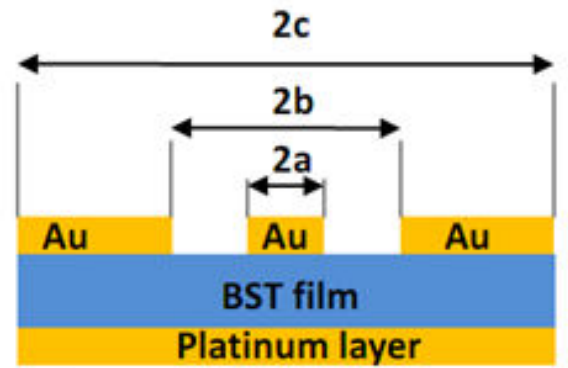

(a)

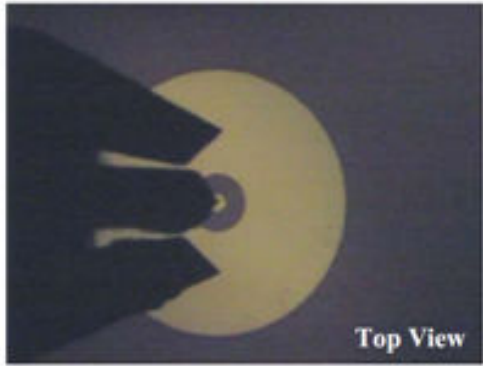

(b)

Fig. 1 : (a) Layout of the fabricated MIM capacitors for the RF measurements, (b) Microscopic top view picture of the structure.

A simplified model of this PPC may be given as shown in Fig. 2.

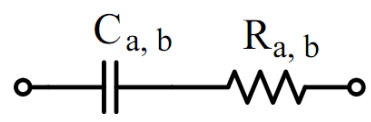

Fig. 2: The equivalent series R-C model of a tunable MIM capacitor where "a" and "b" are suffix denoting the first and second capacitor, respectively.

Where the values of the capacitance and the resistance may be obtained from:

$$
Z_{D U T}=Z_{0}\left(\frac{1+S_{11}}{1-S_{11}}\right)=R_{a, b}+\frac{1}{j \omega C_{a, b}}
$$

\section{3- Results and discuss}

\section{1- $\quad$ Structure and microstructure analysis}

The crystallinity of the films was studied by X-ray analysis. Fig. 3 shows diffractograms of BST70, BST50 and BST30 annealed at the same temperature (Fig. 3(a)) and BST70 annealed at different temperatures (Fig. 3(b)). As we can see, pure BST phase as been synthesized and the thin films are polycrystalline without preferential orientation. Silicon and Platinum diffraction peak can be seen on the XRD pattern, belonging to the substrate. The cell parameters, calculated from the diffractograms and shown in Table 1, are in good agreement with the bulk parameters [21]. For the 
BST70 samples, a cubic structure pattern has been obtained, which let us think that the films are in paraelectric state at ambient temperature. Fig. 4 shows a better definition scan of the (110) peak of BST70. The intensity of the (110) peak increases from 600 to $700{ }^{\circ} \mathrm{C}$ and is then stabilizing between 700 and $800^{\circ} \mathrm{C}$ meaning that the crystallinity is improved with the temperature, reaching its maximum at $800^{\circ} \mathrm{C}$. The full width at half medium (FWHM), decreasing with temperature increase, is associated with the grain size increase.

(a)

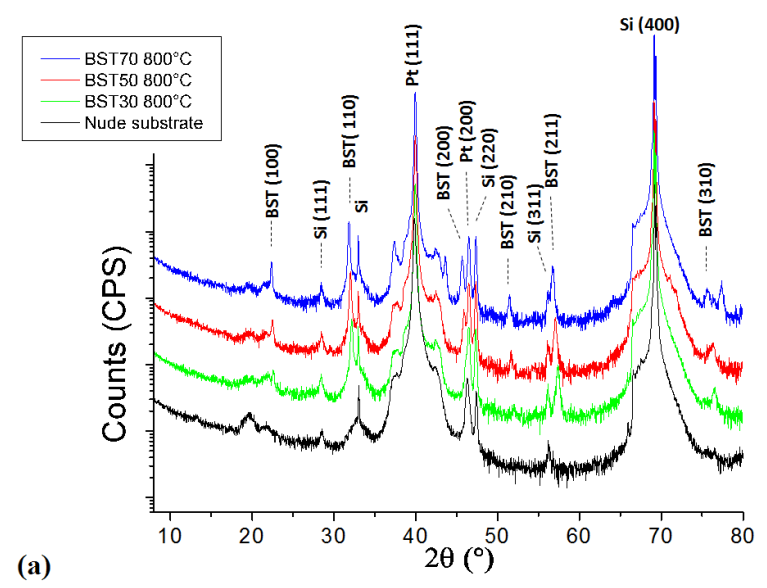

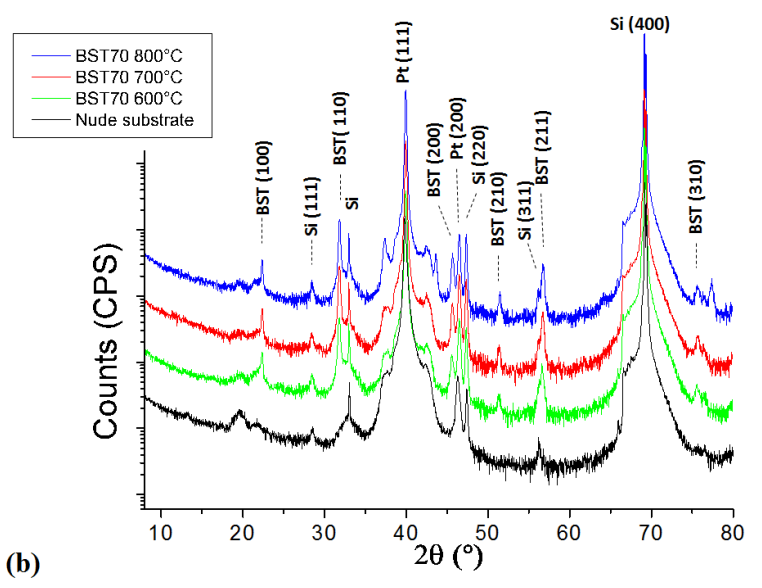

(b)

Fig. 3 : XRD pattern of solgel BST thin films, (a) with different compositions annealed at the same temperature: $800^{\circ} \mathrm{C}$, (b) for BST70 annealed at different temperatures: $600^{\circ} \mathrm{C}, 7^{\circ} \mathrm{C}$ and $800^{\circ} \mathrm{C}$.

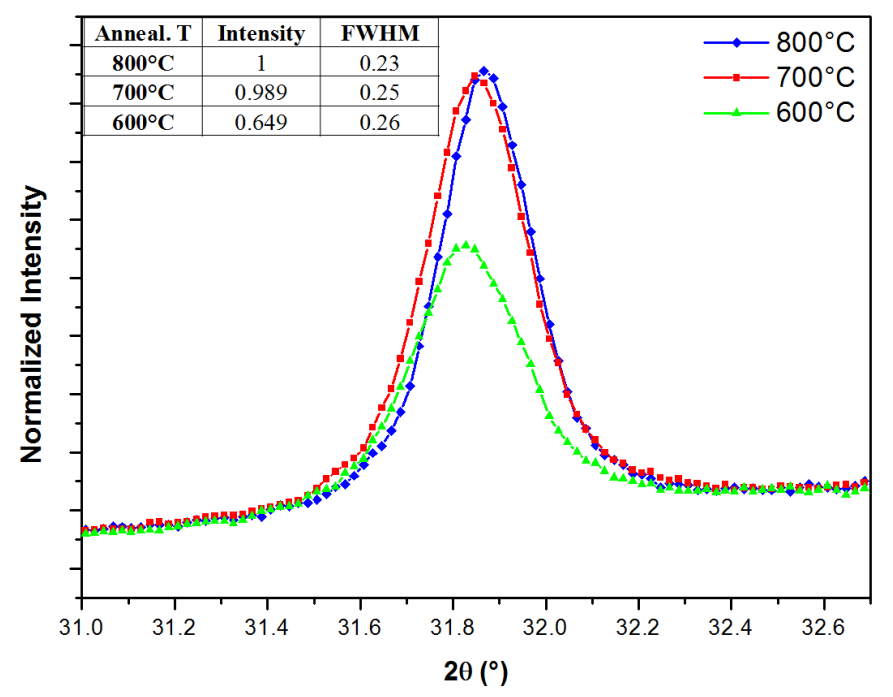

Fig. 4 : XRD centered on the 110 BST70 diffraction peak for different annealing temperature. Inset: table of the intensities and FWHM.

\begin{tabular}{cccc}
\hline Anneal. T & a (BST70) & a (BST50) & a (BST30) \\
\hline $\mathbf{8 0 0}^{\circ} \mathbf{C}$ & $3.97(8) \AA$ & $3.95(3) \AA$ & $3.93(9) \AA$ \\
$\mathbf{7 0 0}^{\circ} \mathbf{C}$ & $3.97(5) \AA$ & $3.95(4) \AA$ & $3.93(6) \AA$ \\
$\mathbf{6 0 0}^{\circ} \mathbf{C}$ & $3.97(5) \AA$ & $3.95(3) \AA$ & $3.93(6) \AA$ \\
\hline Bulk & 3.974 & 3.952 & 3.932 \\
\hline
\end{tabular}

Table 1 : Cell parameter of solgel BST thin films with different compositions and different annealing temperatures. 
Fig. 5 presents the SEM images of the surface of the BST70, BST50 and BST30 films annealed at 600,700 and $800^{\circ} \mathrm{C}$. For each composition, an increase of the grain size with the temperature can readily be seen, which is in agreement with the XRD analysis. For the BST70, the grain size around $30 \mathrm{~nm}$ at $600^{\circ} \mathrm{C}$, is up to $150 \mathrm{~nm}$ at $800^{\circ} \mathrm{C}$. At $600^{\circ} \mathrm{C}$, the majority of the grains are separated by porosity, and the increase of temperature allows then the coalescence of those small grains. The coalescence also leads to a size increase of the intergranular porosity. Moreover, for a same annealing temperature, the grain size increases with raising the $\mathrm{Ba} / \mathrm{Sr}$ ratio. $\mathrm{BaTiO}_{3}$ melting temperature $\left(\mathrm{T}_{\text {melt }}=1618^{\circ} \mathrm{C}\right)$ is indeed smaller than that of $\mathrm{SrTiO}_{3}\left(\mathrm{~T}_{\text {melt }}=2080^{\circ} \mathrm{C}\right)$, then when the $\mathrm{Ba} / \mathrm{Sr}$ ratio is increased, the $T_{\text {anneal. }} / T_{\text {melt }}$ ratio is increased and the grain growth improved. All these surface mappings were confirmed by cross section analysis shown in Fig. 6. As we can see, the out-of-plane grain sizes and morphologies are approximately the same than the top surface: the grains are spherical and disordered.

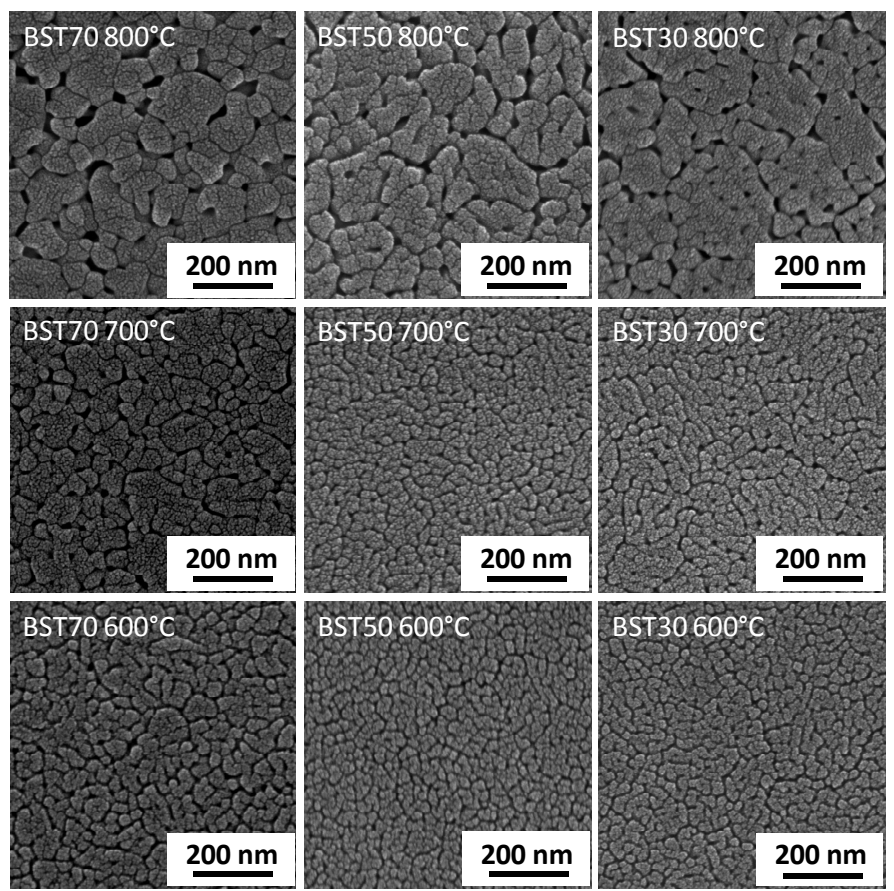

Fig. 5 : SEM images of top surface of solgel BST thin films with different compositions and different annealing temperatures. 


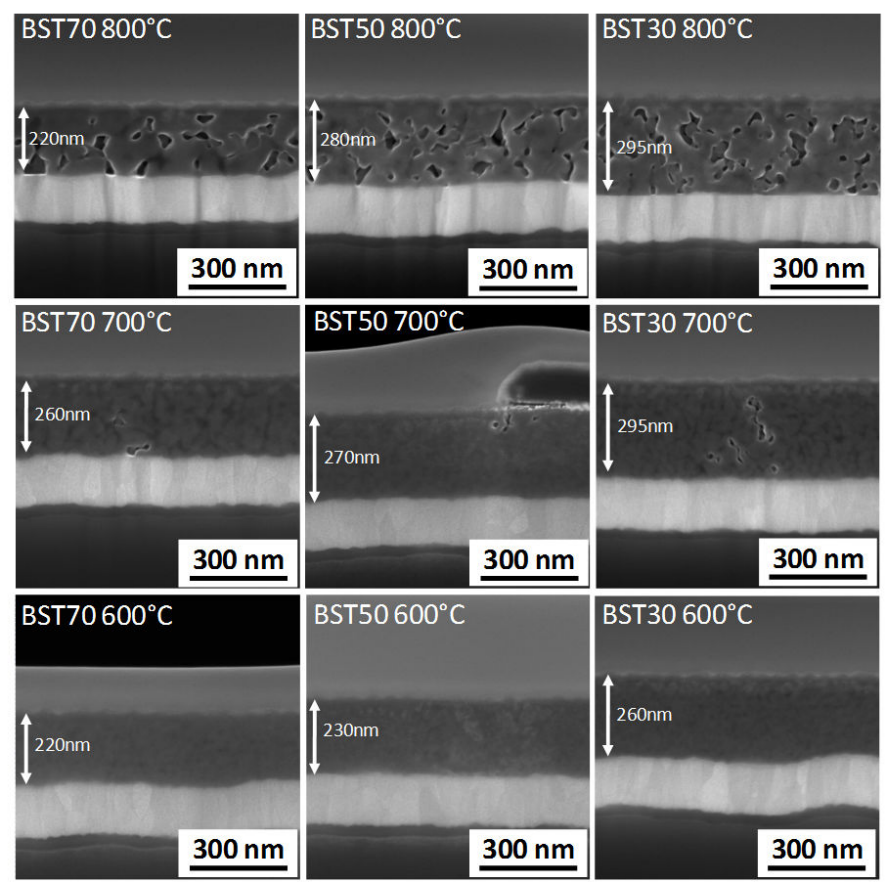

Fig. 6 : SEM images of the cross section of solgel BST thin films with different compositions and different annealing temperatures.

\section{2- Dielectric measurements at low frequency}

The permittivity vs. temperature curves of the thin films measured at $10 \mathrm{kHz}$ are shown in Fig. 7. Diffuse ferroelectric to paraelectric transitions can be seen. For each composition, the same behavior is observed with the increase of the annealing temperature: a global enhancement of the permittivity, sharper transition peaks, and a shift of the transition maxima $T_{m}$ toward higher temperature. Despite this temperature shift of $T_{m}$, for the highest temperature annealed samples the maxima are approximately $25^{\circ} \mathrm{C}$ to $30^{\circ} \mathrm{C}$ lower than the bulk Curie temperature $T_{c}\left(T_{c}\right.$ respectively $30^{\circ} \mathrm{C},-25^{\circ} \mathrm{C}$ and $-100^{\circ} \mathrm{C}$ for BST70, BST50 and BST30 [22]). This result confirms the cubic pattern obtain for BST70 in XRD analysis at ambient temperature. With the increase of the annealing temperature, the films tend to a bulk like behavior. This can be correlated with crystallinity increase and with the grain growth observed on Fig. 4 and Fig. 5. Assuming that the grain core is a high permittivity material and the grain boundary is a low permittivity material, increasing the grain size will decrease the low permittivity volume fraction in the layer and improve the global permittivity. Sinnamon et al investigated the possibility that the dielectric collapse could be due to a grain boundary dead layer, rather than a dead layer interface [23]. This hypothesis is correlated with the dielectric losses at $10 \mathrm{kHz}$ vs. temperature plot presented in Fig. 8. After a $600^{\circ} \mathrm{C}$ heat treatment, there isn't any 
losses peak at the transition temperature, corroborating the presence of a low losses material. The losses anomaly appears for the $700^{\circ} \mathrm{C}$ annealed sample and can be clearly seen after an $800^{\circ} \mathrm{C}$ heat treatment, showing the decreasing of the non-ferroelectric volume fraction such as grain boundaries.

On the other hand, the shift of the transition maximum has been previously discussed using a layered composite model [24], with inclusions of low permittivity layer by Berge et al. [25]. It is shown that the appearing Curie temperature is strongly reduced by increasing the thickness of a dead layer. The presence of an interfacial dead layer could be confirmed by a study with thin films of different thickness, increasing the contribution of the dead layer in the permittivity [26-28], coupled with Transmission Electronic Microscopy at the interface region $[29,30]$.
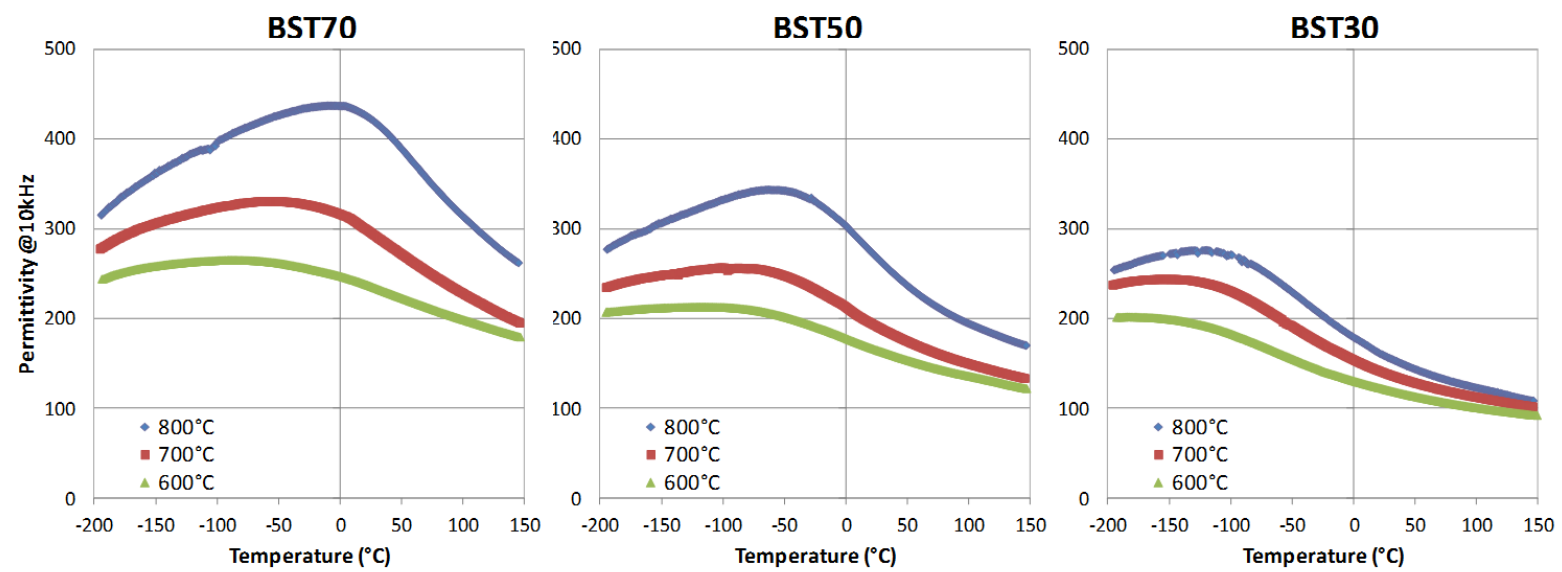

Fig. 7 : Permittivity at $10 \mathrm{kHz}$ as a function of temperature of solgel BST thin films with different compositions and different annealing temperatures.

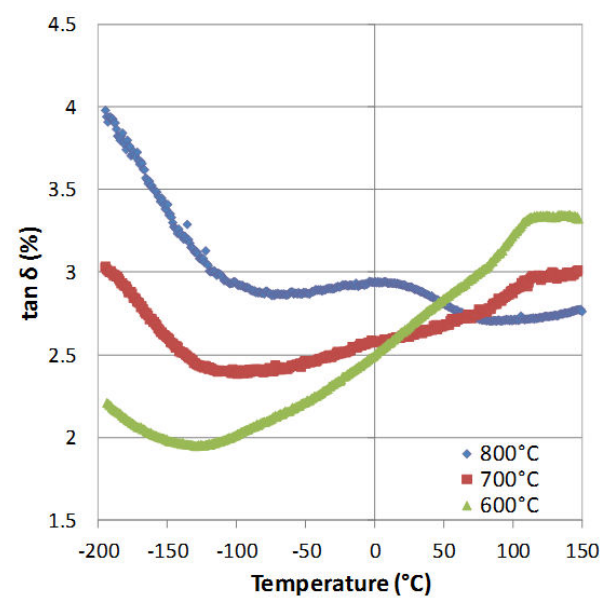

Fig. 8 : Dielectric losses at $10 \mathrm{kHz}$ as a function of temperature for solgel BST70 thin films annealed at different temperatures. 
Dielectric permittivity and losses measured at $10 \mathrm{kHz}$ as a function of external dc electric field at ambient conditions have been performed (Fig. 9). For each composition, the annealing temperature increase leads to an increase of the permittivity and losses at $0 \mathrm{~V}$, and also of the tunability (Table 2). Such behavior is in perfect agreement with the crystallinity and grain size improvement reported in XRD and SEM analysis, and with the presence of low permittivity material with lower temperature heat treatment. The transition shift toward higher temperature observed with the annealing temperature increase also contributes to this dielectric properties improvement.

An increase of the permittivity, losses and tunability is also observed when the $\mathrm{Ba} / \mathrm{Sr}$ ratio is increased. The higher the $\mathrm{Ba}$ content is, the higher is the transition temperature, so at ambient condition the measurement is performed at a temperature closer to the peak. It is well known that the non linearity of a ferroelectric material will be maximal at the Curie temperature; thereby we observe greater tunability when the $\mathrm{Ba}$ content is higher. Nevertheless, a raise of the dielectric losses is also obtained (Fig. 9). A tunability of the losses is observed for the well crystallized sample, confirming a higher ferroelectric material volume fraction. This result is in good agreement with the grain size growth and temperature dependence dielectric measurements.

On the Fig. 9 showing the permittivity and dielectric loss field dependences, a butterfly hysteresis shape that is typical of the ferroelectricity can be observed for the BST70 and BST50. Since the measurement were performed at room temperature, both BST70 and BST50 sample should be in the paraelectric state, as shown in Fig. 7. Different reasons can be found in the literature to explain the origin of this ferroelectric-like behavior in paraelectric thin films. One model proposed by Pontes et al is associated with oxygen vacancies and other space charges effect at the interface between the film and the substrate and/or at the grain boundaries [31]. Such space charges have been observed by TEM by Zhu et al [32]. Another explanation could be the appearance of local regions of ferroelectric polarization. Those polar nanoregions, which have been studied by Raman spectroscopy by Tenne et al [33] would be correlated with the broad peak of the permittivity in the temperature dependence. 

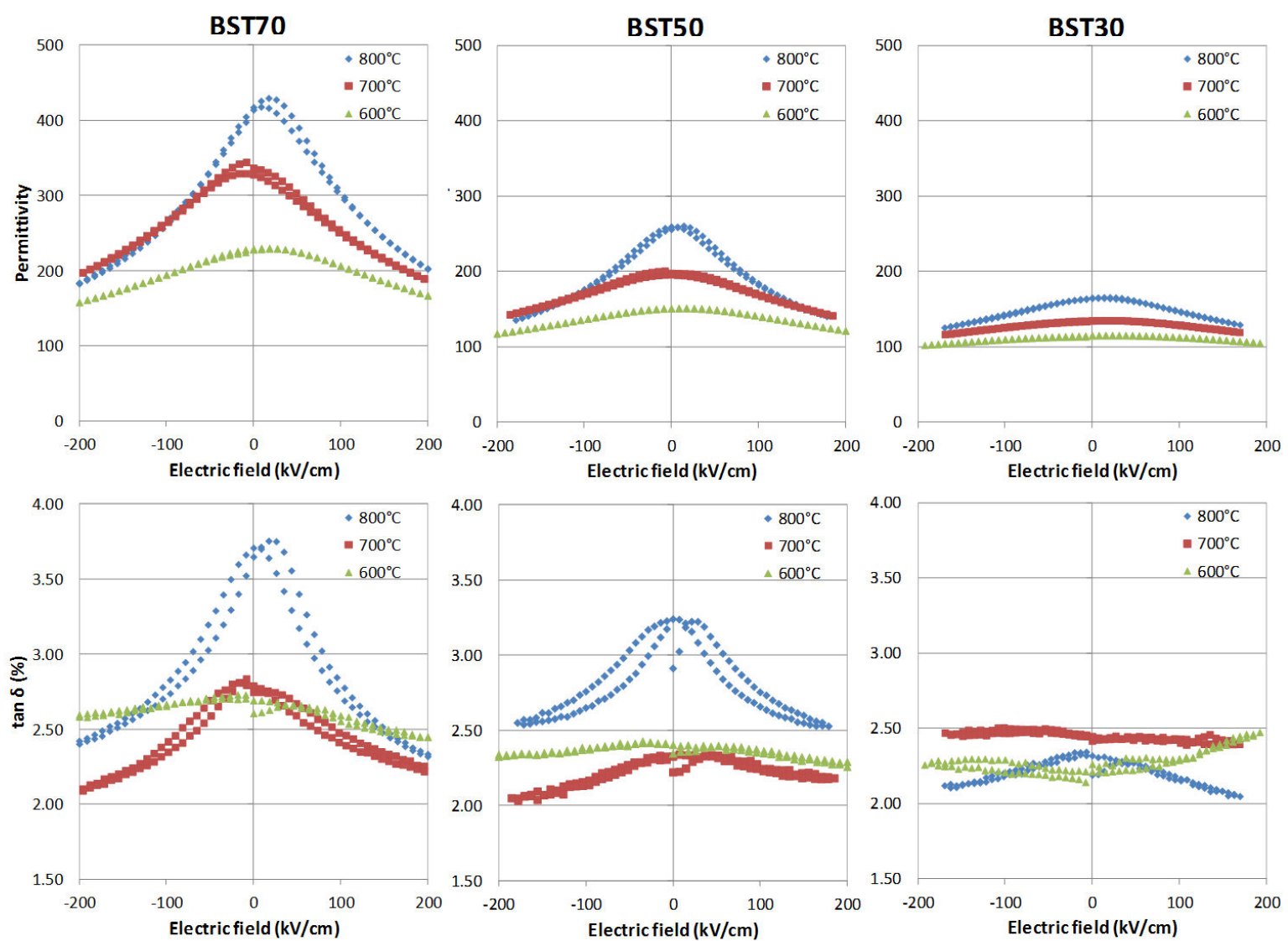

Fig. 9 : Permittivity and dielectric losses at $10 \mathrm{kHz}$ as a function of external electric field for solgel BST thin films with different compositions and different annealing temperatures.

\begin{tabular}{cccc}
\hline Anneal. T & BST70 & BST50 & BST30 \\
\hline $\mathbf{8 0 0}^{\circ} \mathbf{C}$ & $49 \%$ & $40 \%$ & $19 \%$ \\
$\mathbf{7 0 0}^{\circ} \mathbf{C}$ & $36 \%$ & $23 \%$ & $9 \%$ \\
$\mathbf{6 0 0}^{\circ} \mathbf{C}$ & $19 \%$ & $14 \%$ & $5 \%$ \\
\hline
\end{tabular}

Table 2 : Tunability for a $150 \mathrm{kV} / \mathrm{cm}$ external electric field, for solgel BST thin films with different compositions and different annealing temperatures.

\section{3- $R F$ characterization}

RF measurements of the permittivity under different bias of the samples annealed at the higher temperature $800^{\circ} \mathrm{C}$ are presented in Fig. 10 . Without bias, the extracted permittivity is constant on the whole frequency range. Under an electric field, resonances appear around 1, 3 and $5 \mathrm{GHz}$, that may be due to an electrostrictive effect [34]. As shown on Table 3, a very good continuity is obtained between the permittivity at low and high frequency. Moreover, very close values of tunability are measured at low and high frequency. A huge tunability of $70 \%$ is obtained under a $600 \mathrm{kV} \cdot \mathrm{cm}^{-1}$ electric field at $10 \mathrm{GH}$, for the BST70 sample annealed at $800^{\circ} \mathrm{C}$. 

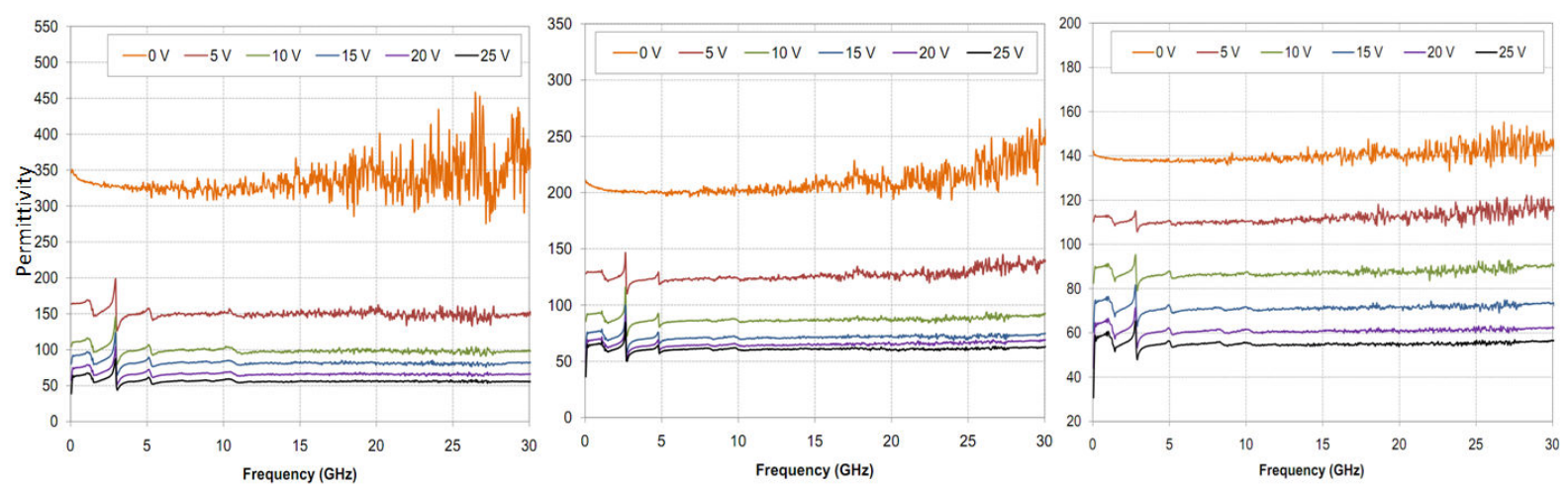

Fig. 10 : Permittivity from $800 \mathrm{MHz}$ to $30 \mathrm{GHz}$, under different bias, of the BST70, BST50 and BST30 samples annealed at $800^{\circ} \mathrm{C}$.

\begin{tabular}{|c|c|c|c|c|c|c|}
\hline & \multicolumn{2}{|c|}{ BST70 $\left(800^{\circ} \mathrm{C}\right)$} & \multicolumn{2}{|c|}{ BST50 $\left(800^{\circ} \mathrm{C}\right)$} & \multicolumn{2}{|c|}{ BST30 $\left(800^{\circ} \mathrm{C}\right)$} \\
\hline Frequency & $10 \mathrm{kHz}$ & $10 \mathrm{GHz}$ & $10 \mathrm{kHz}$ & $10 \mathrm{GHz}$ & $10 \mathrm{kHz}$ & $10 \mathrm{GHz}$ \\
\hline Permittivity & 410 & 325 & 250 & 200 & 160 & 140 \\
\hline $\begin{array}{c}\text { Tunability } \\
@ 150 \mathrm{kV} / \mathrm{cm}\end{array}$ & $49 \%$ & $53 \%$ & $40 \%$ & $39 \%$ & $19 \%$ & $20 \%$ \\
\hline
\end{tabular}

Table 3 : Comparison of the low and high frequency values of permittivity and tunability at $150 \mathrm{kV} / \mathrm{cm}$.

\section{4- Conclusions}

This study has shown the effects of the annealing temperature and the composition of BST solgel thin films on the structure, microstructure and dielectric properties. A good correlation between the crystallinity, the grain size and the dielectric properties has been found. As expected, the increase of the heat treatment temperature increased the crystallinity, the grain size, and also restricted the contribution of non ferroelectric materials such as grain boundaries. These results corroborate the increase of the film permittivity, dielectric losses and tunability at low frequency. A shift of the ferroelectric to paraelectric transition toward the bulk Curie temperature has been observed with the increase of the annealing temperature, suggesting the decrease of a dead layer thickness.

A very reproductive behavior with the annealing temperature has been found for each BST composition. Furthermore, for a given annealing temperature, a clear effect of the $\mathrm{Ba} / \mathrm{Sr}$ ratio has been seen: increasing the Sr content increases the melting point of the material, and mitigates the effect of the heat treatment. Thus, a decrease of the grain size, the dielectric permittivity, losses and tunability has been shown.

The RF results show values of permittivity and tunability in very good agreement with the low frequency results. 


\section{Acknowledgement}

The authors would like to thank Fabien Allanic from STMicroelectronics for the top surface SEM analysis, Céline Bondoux from STMicroelectronics for the thin film depositions, and Mitsubishi Material Corporation for the solgel solutions. Part of this work was supported by the French National Agency for Research under contract ABSYS2.

\section{References}

[1] Baniecki J. D., Laibowitz R. B. , Shaw T. M. , Duncombe P. R., Neumayer D. A., Kotecki D. E., Shen H., Q. Y. Ma., Dielectric relaxation of $\mathrm{Ba}_{0.7} \mathrm{Sr}_{0.3} \mathrm{TiO}_{3}$ thin films from $1 \mathrm{mHz}$ to $20 \mathrm{GHz}$. Appl. Phys. Lett., 1998;72:498-500.

[2] Horikawa T., Mikami N., Makita T., Tanimura J., Kataoka M., Sato K. et al., Dielectric properties of (Ba,Sr) $\mathrm{TiO}_{3}$ thin films deposited by RF sputtering. Jpn. J. Appl. Phys., 1993;32:4126-4130.

[3] Chrisey D.B., Hubler. G.K., Pulsed Laser Deposition of Thin Films. Wiley Interscience, New York; 1994.

[4] Burhanuddin Z.A., Tomar M.S., Dayalan E., $\mathrm{Ba}_{\mathrm{x}} \mathrm{Sr}_{1-\mathrm{x}} \mathrm{TiO}_{3}$ thin films by a chemical process. Thin Solid Films, 1994;253:53-56.

[5] Tian H Y, Luo W G, Pu X H, He X Y, Qiu P S, Ding A L et al, Determination of the optical properties of sol-gel-derived $\mathrm{Ba}_{\mathrm{x}} \mathrm{Sr}_{1-\mathrm{x}} \mathrm{TiO}_{3}$ thin film by spectroscopic ellipsometry. J. Phys.: Condens. Matter, 2001;13:4065.

[6] Yang S H, Mo D, Tian H Y, Luo W G, Pu X H, Ding A L, Spectroscopic Ellipsometry of $\mathrm{Ba}_{\mathrm{x}} \mathrm{Sr}_{1-}$ ${ }_{x} \mathrm{TiO}_{3}$ Thin Films Prepared by the Sol-Gel. Method Phys. Stat. Sol. (a), 2002;612605:612.

[7] Leng W. J., Yang C. R., Zhang J. H., Chen H. W., Ji H., Fu C. L., et al., Structural and optical properties of $\mathrm{Ba}_{\mathrm{x}} \mathrm{Sr}_{1-\mathrm{x}} \mathrm{TiO}_{3}$ thin films on indium tin oxide/quartz substrates prepared by radiofrequency magnetron sputtering. J. Appl. Phys., 2006;99:114904.

[8] Wang G. S. , Zhang Y. Y. , Mao C. L. , Dong X. L. , Chu J. H. , Composition dependence of structural and optical properties for sol- gel derived (100)-oriented $\mathrm{Ba}_{1-\mathrm{x}} \mathrm{Sr}_{\mathrm{x}} \mathrm{TiO}_{3}$ thin films. Appl. Phys. Lett., 2007;91:061104.

[9] Jian S R , Chang W J , Fang T H , Ji L W , Hsiao Y J , Chang Y S , Nanomechanical characteristics of $\mathrm{Ba}_{\mathrm{x}} \mathrm{Sr}_{1-\mathrm{x}} \mathrm{TiO}_{3}$ thin films. Mater Sci Eng B, 2006;131: 281-284.

[10] Kribalis S. , Tsakiridis P. E. ,Dedeloudis C. , Hristoforou E., Structural and electrical characterization of barium strontium titanate films prepared by sol-gel technique on brass $(\mathrm{CuZn})$ substrate. J Optoelectron Adv M, 2006;8:1475-1478.

[11] Panda B., Roy A., Dhar A., Ray S. K., Thickness and temperature dependent electrical characteristics of crystalline $\mathrm{Ba}_{\mathrm{x}} \mathrm{Sr}_{1-\mathrm{x}} \mathrm{TiO}_{3}$ thin films. J. Appl. Phys., 2007;101:064116.

[12] Wang S.Y. Cheng, B.L., Wang C., Peng W., Dai S.Y., Chen Z.H., Dielectric and Ferroelectric Properties of $\mathrm{Ba}_{1-\mathrm{x}} \mathrm{Sr}_{\mathrm{x}} \mathrm{TiO}_{3}$ Thin Films Prepared by Pulsed Laser Deposition. Key Eng Mater, 2005;280:81-84.

[13] Zhu X., Zhu J. , Zhou S., Liu Z., Ming N. , Lu S. et al, Recent Progress of (Ba,Sr)TiO 3 Thin Films for Tunable Microwave Devices. J. Electron. Mater., 2003;32:1125-1134. 
[14] Ioachim A., Toacsan M.I., Banciu M.G., Nedelcu L., Vasiliu F. , Alexandru H.V. et al, Barium strontium titanate-based perovskite materials for microwave applications. Prog. Solid State Chem., 2007;35:513-520.

[15] Costa L.C. , Aoujgal A. , Graça M.P.F. , Hadik N. , Achour M.E. , Tachafine A. et al., Microwave dielectric properties of the system $\mathrm{Ba}_{1-\mathrm{x}} \mathrm{Sr}_{\mathrm{x}} \mathrm{TiO}_{3}$. Physica $B, 2010 ; 405: 3741-3744$.

[16] Knauss L. A., Pond J. M., Horwitz J. S., Chrisey D. B., Mueller C. H., Treece R., Appl. Phys. Lett., The effect of annealing on the structure and dielectric properties of $\mathrm{Ba}_{\mathrm{x}} \mathrm{Sr}_{1-\mathrm{x}} \mathrm{TiO}_{3}$ ferroelectric thin films. 1996;69:25-27.

[17] Nayak M, Lee S.Y, Tseng T.Y, Electrical and dielectric properties of $\left(\mathrm{Ba}_{0.5} \mathrm{Sr}_{0.5}\right) \mathrm{TiO}_{3}$ thin films prepared by a hydroxide-alkoxide precursor-based sol-gel method. Mater. Chem. Phys., 2003;77:3442.

[18] Lu H., Pan J. S., Chen X. F., Zhu W. G., Tan O. K., Influence of annealing temperature on the band structure of sol-gel $\mathrm{Ba}_{0.65} \mathrm{Sr}_{0.35} \mathrm{TiO}_{3}$ thin films on n-type $\mathrm{Si}(100)$. Appl. Phys. Lett., 2006;88:132907.

[19] Wu W, Peng D, Ding Y, Meng Z, Dielectric tunable properties of $\left(\mathrm{Ba}_{1-\mathrm{x}} \mathrm{Sr}_{\mathrm{x}}\right) \mathrm{TiO}_{3}$ thin films on $\mathrm{LaAlO}_{3}$ substrate. Mater. Sci. Semicond. Process., 2001;4:673-678.

[20] Ma Z, Becker A.J., Polakos P., Huggins H., Pastalan J., Hui Wu et al., RF Measurement Technique for Characterizing Thin Dielectric Films. IEEE Trans Electron Devices, $1998 ; 45$ :18111816.

[21] McQuarrie, Malcolm, Structural Behavior in the System (Ba, Ca, Sr) $\mathrm{TiO}_{3}$ and its relation to certain dielectric characteristics. J. Am. Ceram. Soc., 1955;38:444-449.

[22] Smolenskii G. A., Isupov V. A., Ferroelectric Properties of Solid Solutions of Barium Stannate in Barium Titanate. Sov. J. Techn. Phys., 1954;24:1375.

[23] Sinnamon L. J., Saad M. M., Bowman R. M., Gregg J. M., Exploring grain size as a cause for “dead-layer" effects in thin film capacitors. Appl. Phys. Lett., 2002;81:703-705.

[24] Tagantsev A.K., Sherman V.O., Astafiev K.F., Venkatesh J., Setter N.. Ferroelectric materials for microwave tunable applications. J Electroceram, 2003;11:5.

[25] Berge J., Vorobiev A., Gevorgian S., The effect of growth temperature on the nanostructure and dielectric response of $\mathrm{BaTiO}_{3}$ ferroelectric films. Thin Solid Films, 2007;515:6302-6308.

[26] Zhou C., Newns D. M., Intrinsic dead layer effect and the performance of ferroelectric thin film capacitors. J. Appl. Phys., 1997;82:3081-3088.

[27] Lee B.T., Hwang C.S., Influences of interfacial intrinsic low-dielectric layers on the dielectric properties of sputtered (Ba,Sr)TiO 3 thin films. Appl. Phys. Lett., 2000;77:124-126.

[28] Park WY, Hwang CS, Film-thickness-dependent Curie-Weiss behavior of $(\mathrm{Ba}, \mathrm{Sr}) \mathrm{TiO}_{3}$ thin-film capacitors having Pt electrodes. Appl. Phys. Lett., 2004;85: 5313-5315.

[29] Liao J.X., Yang C.R., Zhang J.H., Fu C.L., Chen H.W., Leng W.J., The interfacial structures of $(\mathrm{Ba}, \mathrm{Sr}) \mathrm{TiO}_{3}$ films deposited by radio frequency magnetron sputtering. Appl. Surf. Sci., 2006;252:74077414.

[30] Chen HW, Yang CR, Fu CL, Zhang JX, Liao JX, Hu L, Effects of interface on the dielectric properties of $\mathrm{Ba}_{0.6} \mathrm{Sr}_{0.4} \mathrm{TiO}_{3}$ thin film capacitors. Appl. Surf. Sci., 2008;254:3175-3179. 
[31] Pontes FM, Leite ER, Longo E, Varela JA, Araujo EB, Eiras JA, Effects of the postannealing atmosphere on the dielectric properties of $(\mathrm{Ba}, \mathrm{Sr}) \mathrm{TiO}_{3}$ capacitors: Evidence of an interfacial space charge layer. Appl. Phys Lett., 2000;76:2433-2435.

[32] Zhu XH, Yong LP, Tian HF, Peng W, Li JQ, Zheng DN, The origin of the weak ferroelectric-like hysteresis effect in paraelectric $\mathrm{Ba}_{0.5} \mathrm{Sr}_{0.5} \mathrm{TiO}_{3}$ thin films grown epitaxially on $\mathrm{LaAlO}_{3}$. J. Phys.: Condens. Matter, 2006;18:4709-4718.

[33] Tenne DA, Soukiassian A, Zhu MH, Clark AM, Xi XX, Choosuwan H et al, Raman study of $\mathrm{Ba}_{\mathrm{x}} \mathrm{Sr}_{1-\mathrm{x}} \mathrm{TiO}_{3}$ films: Evidence for the existence of polar nanoregions. Phys. Rev. B, 2003;67:012302

[34] Gevorgian S., Vorobiev A., Lewin T., dc field and temperature dependent acoustic resonances in parallel-plate capacitors based on $\mathrm{SrTiO}_{3}$ and $\mathrm{Ba}_{0.25} \mathrm{Sr}_{0.75} \mathrm{TiO}_{3}$ films: Experiment and modeling. J. Appl. Phys., 2006;99:124112

\section{Figure captions :}

Fig. 1 : (a) Layout of the fabricated MIM capacitors for the RF measurements, (b) Microscopic top view picture of the structure

Fig. 2 : The equivalent series R-C model of a tunable MIM capacitor where "a" and " $b$ " are suffix denoting the first and second capacitor, respectively.

Fig. 3 : XRD pattern of solgel BST thin films, (a) with different compositions annealed at the same temperature: $800^{\circ} \mathrm{C}$, (b) for BST70 annealed at different temperatures: $600^{\circ} \mathrm{C}, 700^{\circ} \mathrm{C}$ and $800^{\circ} \mathrm{C}$.

Fig. 4 : XRD centered on the 110 BST70 diffraction peak for different annealing temperature. Inset: table of the intensities and FWHM.

Fig. 5 : SEM images of top surface of solgel BST thin films with different compositions and different annealing temperatures.

Fig. 6 : SEM images of the cross section of solgel BST thin films with different compositions and different annealing temperatures.

Fig. 7 : Permittivity at $10 \mathrm{kHz}$ as a function of temperature of solgel BST thin films with different compositions and different annealing temperatures.

Fig. 8 : Dielectric losses at $10 \mathrm{kHz}$ as a function of temperature for solgel BST70 thin films annealed at different temperatures.

Fig. 9 : Permittivity and dielectric losses at $10 \mathrm{kHz}$ as a function of external electric field for solgel BST thin films with different compositions and different annealing temperatures.

Fig. 10 : Permittivity from $800 \mathrm{MHz}$ to $30 \mathrm{GHz}$, under different bias, of the BST70, BST50 and BST30 samples annealed at $800^{\circ} \mathrm{C}$.

\section{$\underline{\text { Table Captions : }}$}

Table 1 : Cell parameter of solgel BST thin films with different compositions and different annealing temperatures.

Table 2: Tunability for a $150 \mathrm{kV} / \mathrm{cm}$ external electric field, for solgel BST thin films with different compositions and different annealing temperatures. 
Table 3: Comparison of the low and high frequency values of permittivity and tunability at $150 \mathrm{kV} / \mathrm{cm}$. 